\title{
FERTILITY AND MALE-CHILD PREFERENCE IN IMPHAL EAST DISTRICT, MANIPUR: A CROSS- SECTIONAL STUDY
}

\author{
Nandeibam Kameshore', Heisnam Kulabidhu Singh ${ }^{2}$
}

${ }^{1}$ Associate Professor, Department of Paediatrics, JNIMS.

${ }^{2}$ Associate Professor, Department of Community Medicine, JNIMS.

\section{ABSTRACT}

The harmful impacts of having too many children need not be overemphasised. Many factors influence the Total Fertility Rate (TFR). An important one of them is male-child preference, which is still seen in the South-East Asia Region including India. Based on the latest National Family Health Survey-4 Report, Ministry of Health and FW, Govt. of India, the state of Manipur was still having a quite high TFR of 2.6. The current study was taken up to make an estimate of the total fertility rate to explore presence of son preference and also to study the other prevailing factors, which might influence the fertility in the Imphal East District of Manipur.

\section{MATERIALS AND METHODS}

A cross-sectional study was taken up in Imphal East District of Manipur during March-May 2016 among a representative sample of 403 women of reproductive age group. Trained female interviewers collected data by using an interview schedule, which had sections on socio-demographic profile, fertility pattern and preferences, male-child preference, and decision taking on fertility after obtaining informed verbal consent. Ethical approval for the study was obtained from IEC, JNIMS. Data analysis was done using SPSSv22.

\section{RESULTS}

Completed data sets were collected from 384 study subjects from the three major communities residing in the study area (Muslims-190, Hindus-139, and Tribal-55). The estimated total fertility rate of the study area was 2.0, the highest being among the Muslim community (2.2). The proportion of Muslim women having $\geq 3$ children was higher than the other two remaining communities $(\mathrm{p}=0.001)$. Educational status and occupation of the study subjects were closely associated with the number of children. Higher proportion of the Muslim women desired to have $\geq 3$ children compared to Hindu and Tribal communities ( $p=0.001$ ). Educational status and occupation of the women had significant relation with this. There was no male-child preference detected.

\section{DISCUSSION}

The total fertility rate of Imphal East District of Manipur was found to be lower (2.0) than the State figure of 2.6 as reported in NFHS-4 Report. TFR being highest among the Muslim community was against findings made earlier in 2009 by other researchers. Education and occupation of the mothers being significant factors influencing the number of children were comparable to other study findings. The presence of male-child preference could not be detected in the study area.

\section{CONCLUSION}

Muslims were found to be having more children compared to the Hindus or the tribal community. Education and occupation were significant factors influencing the fertility. Male-child preference was not distinctly seen in the study area.

\section{KEYWORDS}

Fertility, Male-Child Preference, Sex Preference.

HOW TO CITE THIS ARTICLE: Kameshore N, Singh HK. Fertility and male-child preference in Imphal east district, Manipur: a crosssectional study. J. Evolution Med. Dent. Sci. 2016;5(60):4207-4210, DOI: 10.14260/jemds/2016/960

\section{INTRODUCTION}

The harmful impacts of having too many children need not be overemphasised. Many factors influence the TFR. An important one of them is male-child preference, which is still seen in the South-East Asia including India.1-2 It is also known that couples in developing countries have higher fertility and son preference. ${ }^{3}$ Various factors which have an influence on son preference like mother's education, religious factors, perceived need of having someone to take care during old age, socio-economic factors etc. are well documented for. ${ }^{4-6}$

Financial or Other, Competing Interest: None.

Submission 22-06-2016, Peer Review 15-07-2016,

Acceptance 21-07-2016, Published 28-07-2016.

Corresponding Author:

Dr. Heisnam Kulabidhu Singh,

Associate Professor

Department of Community Medicine,

JNIMS, Imphal-795005,

Manipur.

E-mail:kb_heisnam@rediffmail.com

DOI: 10.14260/jemds/2016/960
The latest National Family Health Survey Report 2015-16 published by the Ministry of Health and Family Welfare, Government of India shows a high Total Fertility Rate (TFR) of 2.6 for the State of Manipur against the desired goal of 2.1.7 Hence, it was felt important to study the reasons for having a high TFR in the state. The present study was taken up: (i) To estimate Total Fertility Rate (TFR) of the Imphal East District of Manipur, (ii) To explore the presence of male-child preference, and also (iii) to study factors influencing the TFR.

\section{MATERIALS AND METHODS}

A community-based cross-sectional study was taken up in the Imphal East District of Manipur during the period March-May 2016. The study subjects were currently married women of the reproductive age-group of 15-45 years. Women who are widowed, divorced, undergone hysterectomy operation, on medical treatment for primary sterility, or not willing to participate in the study were excluded. A sample size of 403 was calculated based on the assumption of $50 \%$ son preference (To get the maximum sample size), 95\% 
confidence level, an allowable error of $10 \%$, and an anticipated refusal rate of $10 \%$. A multi-stage sampling method was used to get this sample. First, three villages having major communities (Hindu, Muslim, and tribal) were selected by drawing lottery. Secondly, households from these three selected villages were selected randomly keeping the number proportionate to size of the villages. Lastly, one eligible study subject was selected from each of the selected households. If more than one eligible woman was found residing in the same household, only one was selected by drawing lottery.

A pre-tested, semi-structured interview schedule translated into the local dialect was used to collect data. The interview schedule had sections on socio-demographic profile, fertility pattern and preferences, male-child preference, and decision taking on fertility. A group of trained female interviewers collected the data after obtaining informed verbal consent. Confidentiality was maintained during data maintenance and analysis. Ethical approval for the study was obtained from the Institutional Ethics Committee of JN Institute of Medical Sciences, Imphal.

Data collected were entered and analysed in SPSSv22. Both descriptive statistics (mean SD \%) and analytical test $\left(\mathrm{x}^{2}\right)$ were used the later for correlating association between fertility preference to identified background characteristics of the study subjects. P-value of less than 0.05 was taken as significant.

\section{RESULTS}

Completed data sets could be collected from 384 eligible women giving a response rate of $95.3 \%$.

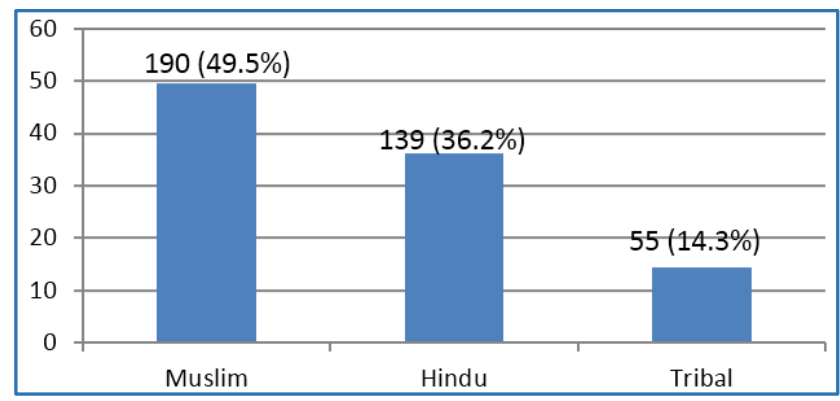

Fig. 1: Study Subjects by Type of Community

Fig. 1 shows the composition of the study subjects by the type of community. Half of the study subjects (190) were Muslims, 139 (36\%) belonged to the Hindu community, and the remaining $55(14 \%)$ were from the tribal community who were all Christians. The mean age of all the study subjects was 31.7 (SD \pm 7.4 ) years. The study women from the Muslim community seemed a little younger with a mean age of 29.2 ( $\mathrm{SD} \pm 7.3$ ) years.

The estimated total fertility rate of the study area was found to be 2.0 with slight variations among the three communities (Muslim-2.2, Tribal-1.9, and Hindu-1.7).

\begin{tabular}{|c|c|c|c|}
\hline \multirow{2}{*}{$\begin{array}{c}\text { Type of } \\
\text { Community }\end{array}$} & \multicolumn{2}{|c|}{$\begin{array}{c}\text { No. of Study Subjects } \\
\text { having }(n=384)\end{array}$} & \multirow{2}{*}{$\begin{array}{c}\text { p- } \\
\text { value } \\
\left(\mathrm{x}^{2}\right)\end{array}$} \\
\hline & $\begin{array}{l}\leq 2 \text { children } \\
(\%)\end{array}$ & $\begin{array}{c}\geq 3 \text { children } \\
\text { (\%) }\end{array}$ & \\
\hline Muslim & $120(63.2)$ & $70(36.8)$ & \multirow{3}{*}{0.001} \\
\hline Hindu & $116(83.5)$ & $23(16.5)$ & \\
\hline Tribal & $39(71.6)$ & $16(29.1)$ & \\
\hline Table 1: S & $\begin{array}{l}\text { y Subjects by } \\
\text { Number of }\end{array}$ & $\begin{array}{l}\text { pe of Commu } \\
\text { ildren }\end{array}$ & \\
\hline
\end{tabular}

More Muslim women were found to be having $\geq 3$ children compared to the two other communities and this difference was found to be statistically significant. This is in spite of the fact that the mean age of Muslim study subjects were comparatively younger than the women of the other two communities.

\begin{tabular}{|c|c|c|c|}
\hline \multirow{2}{*}{ Characteristics } & \multicolumn{2}{|c|}{$\begin{array}{c}\text { Number of Study } \\
\text { Subjects having }\end{array}$} & \multirow{2}{*}{$\begin{array}{c}\text { P-value } \\
\left(\mathrm{x}^{2}\right)\end{array}$} \\
\hline & $\begin{array}{c}\leq 2 \text { Children } \\
(\%)\end{array}$ & $\begin{array}{c}\geq 3 \text { Children } \\
(\%)\end{array}$ & \\
\hline $\begin{array}{l}\text { Educational Level } \\
\text { - } \quad \text { Up to primary } \\
\text { school } \\
\text { - } \quad \text { Up to high school } \\
\text { - } \quad \text { Intermediate and } \\
\text { above }\end{array}$ & $\begin{array}{l}32(42.7) \\
132(75.0) \\
111(83.5)\end{array}$ & $\begin{array}{l}43(57.3) \\
44(25.0) \\
22(16.5)\end{array}$ & 0.001 \\
\hline $\begin{array}{ll}\text { Occupation } \\
\text { - } & \text { Professional/Semi- } \\
& \text { professional } \\
\text { - } & \text { Skilled } \\
\text { - } & \text { Unskilled } \\
\text { - } & \text { Unemployed }\end{array}$ & $\begin{array}{c}23(92.0) \\
38(60.3) \\
42(75.0) \\
172(71.7)\end{array}$ & $\begin{array}{l}2(8.0) \\
25(39.7) \\
14(25.0) \\
68(28.3)\end{array}$ & 0.025 \\
\hline $\begin{array}{l}\text { Monthly Family } \\
\text { Income (Rs.) } \\
\text { - } \quad \text { Up to } 4893 \\
\text { - } \quad 4894-19674 \\
\text { - } \quad 19575 \text { and above }\end{array}$ & $\begin{array}{c}38(74.5) \\
159(69.1) \\
78(75.7)\end{array}$ & $\begin{array}{l}13(25.5) \\
71(31.9) \\
25(24.3)\end{array}$ & 0.414 \\
\hline
\end{tabular}

The study subjects' educational status and occupation were found to be significant factors influencing the number of children. The more the study subjects were educated they were more likely to have up to two children only. Women in the professional and semi-professional group of occupation were least likely to have $\geq 3$ children compared to other groups of occupation. Family income did not have any significant association with the number of children.

\begin{tabular}{|c|c|c|c|}
\hline \multirow{2}{*}{$\begin{array}{c}\text { Type of } \\
\text { Community }\end{array}$} & \multicolumn{2}{|c|}{$\begin{array}{c}\text { No. of Study Subjects } \\
\text { Desiring to have }(n=384) \\
\end{array}$} & \multirow{2}{*}{$\begin{array}{c}\text { p- } \\
\text { value } \\
\left(\mathrm{x}^{2}\right)\end{array}$} \\
\hline & $\begin{array}{c}\leq 2 \text { Children } \\
(\%)\end{array}$ & $\begin{array}{c}\geq 3 \text { Children } \\
(\%)\end{array}$ & \\
\hline Muslim & $95(50.0)$ & $95(50.0)$ & \multirow{3}{*}{0.001} \\
\hline Hindu & 97 (69.8) & $42(30.2)$ & \\
\hline Tribal & $35(63.6)$ & $20(36.4)$ & \\
\hline & $\begin{array}{r}\text { Subjects by } \\
\text { Number o }\end{array}$ & $\begin{array}{l}\text { e of Commu } \\
\text { ldren }\end{array}$ & and \\
\hline
\end{tabular}

Compared to other communities, a higher proportion $(50 \%)$ of Muslim women was found desiring for three or more children. This difference was found to be statistically significant. 


\begin{tabular}{|c|c|c|c|}
\hline \multirow{2}{*}{ Characteristics } & \multicolumn{2}{|c|}{$\begin{array}{c}\text { Number of } \\
\text { Study Subjects } \\
\text { Desired to have }\end{array}$} & \multirow{2}{*}{$\begin{array}{c}\text { P- } \\
\text { value } \\
\left(x^{2}\right)\end{array}$} \\
\hline & $\begin{array}{c}\leq 2 \\
\text { Children } \\
(\%)\end{array}$ & $\begin{array}{c}\geq 3 \\
\text { Children } \\
(\%)\end{array}$ & \\
\hline $\begin{array}{l}\text { Educational Level } \\
\text { - } \quad \text { Up to Primary } \\
\text { School } \\
\text { - } \quad \text { Up to High School } \\
\text { - Intermediate and } \\
\quad \text { Above }\end{array}$ & $\begin{array}{l}23(30.7) \\
109(61.9) \\
95(71.4)\end{array}$ & $\begin{array}{l}52(69.3) \\
67(38.1) \\
38(28.6)\end{array}$ & 0.001 \\
\hline $\begin{array}{l}\text { Occupation } \\
\text { - } \quad \text { Professional/Semi- } \\
\text { Professional } \\
\text { - Skilled } \\
\text { - Unskilled } \\
\text { - Unemployed }\end{array}$ & $\begin{array}{l}23(92.0) \\
38(60.3) \\
42(75.0) \\
172(71.6)\end{array}$ & $\begin{array}{l}2(8.0) \\
25(39.7) \\
14(25.0) \\
68(28.3)\end{array}$ & 0.025 \\
\hline $\begin{array}{l}\text { Monthly Family } \\
\text { Income (Rs.) } \\
\text { - } \quad \text { Up to } 4893 \\
\text { - } \quad 4894-19674 \\
\text { - } \quad 19575 \text { and above }\end{array}$ & $\begin{array}{c}31(60.8) \\
130(56.5) \\
66(64.1)\end{array}$ & $\begin{array}{c}20(39.2) \\
100(43.5) \\
37(35.9)\end{array}$ & 0.417 \\
\hline $\begin{array}{l}\text { Table 4: Study } \\
\text { Characteristic }\end{array}$ & mber of & $\begin{array}{l}\text { r Backgro } \\
\text { Idren Desi }\end{array}$ & \\
\hline
\end{tabular}

The educational level and occupation of the study subjects were found to be related to the number of children they desired to have. The desire to have more children was found to be higher among the lowly educated women. Lesser number of professional/semi-professional women were found to desire for having bigger family size compared to women of other occupations or unemployed women. Family income did not have any significant relation with the number of children desired.

\begin{tabular}{|c|c|c|c|c|}
\hline \multirow{2}{*}{$\begin{array}{c}\text { Type of } \\
\text { Community }\end{array}$} & \multicolumn{3}{|c|}{$\begin{array}{c}\text { Number of Study Subjects } \\
\text { Preferring to have }\end{array}$} & \multirow{2}{*}{$\begin{array}{c}\text { P-value } \\
\left(\mathbf{x}^{2}\right)\end{array}$} \\
\cline { 2 - 4 } & $\begin{array}{c}\text { More Girls } \\
\text { than Boys }\end{array}$ & $\begin{array}{c}\text { More Boys } \\
\text { than Girls }\end{array}$ & $\begin{array}{c}\text { No } \\
\text { Preference }\end{array}$ & \\
\hline Muslim & $31(16.3)$ & $61(32.1)$ & $98(51.6)$ & \multirow{2}{*}{0.203} \\
\hline Hindu & $31(22.5)$ & $31(22.5)$ & $76(55.1)$ & \\
\hline Tribal & $7(12.7)$ & $15(27.3)$ & $33(60)$ & \\
\hline Total & $\mathbf{6 9 ( 1 8 )}$ & $\mathbf{1 0 7}(\mathbf{2 7 . 9 )}$ & $\mathbf{2 0 7}(\mathbf{5 4 )})$ & \\
\hline \multicolumn{4}{|c|}{ Table 5: Study Subjects by Type of Community } \\
and Male-Child Preference \\
\hline
\end{tabular}

For majority of the study subjects $(207,54 \%)$ no malechild preference over female-child was seen. No significant difference on male-child preference was detected among the three communities.

The current study also analysed the data for any association between number of children and husbands' background characteristics and did not find any statistically significant association with the husbands' educational status $(p=0.18)$ and occupation of the husband $(p=0.414)$. Further, husbands' background characteristics were analysed to find out for any association with the desired number of children. Husbands' educational status was found to influence the number of children desired: lower level of education related with the desire to have more children $(p=0.001)$. The husbands' occupation did not have any relation with the desired number of children ( $\mathrm{p}=0.656)$.

Lastly, the current study found that for majority of the study subjects $(309 ; 80.5 \%)$ the decision on fertility was taken jointly by the couple. This was comparable among the three different communities.

\section{DISCUSSION}

The Total Fertility Rate (TFR) of the study area among the three communities was (i) 2.2 among the Muslim community, (ii) 1.9 among the tribal community, and (iii) 1.7 among the Hindu community. All of these values were lower than the one reported in the latest NFHS-4 Report. ${ }^{7}$ The present study being confined to only a single district situated in the better developed area of the state might be the reason of finding a lower TFR.

The current study finding that having three or more children being more prevalent among the Muslim community was in contrast to the finding made by Sharat NS et al 6 in 2009 that the TFR was highest among the Tribal community when compared to the non-tribal community. The seven years' difference in the timing of the studies may explain the change.

Asghar $\mathrm{MD}^{2}$ et al found association between mother's occupation and number of children. The current study reaffirmed this. Further, the current study showed that mother's occupation had an impact on the desired number of children.

The finding that Muslims desiring to have three or more children more than the Hindu and tribal community as found out from the current study could not be compared with other research reports as they were not existent.

The current study finding of educated women preferring to have lesser number of children was comparable with other study reports made earlier.1,4

The significant relationship between fertility preference and the husbands' educational status might because of the tendency of educated women getting married to educated men.

\section{CONCLUSION AND RECOMMENDATIONS}

The total fertility rate in the Imphal East District of Manipur was found to be 2.0. It was highest among the Muslim community (2.2) compared to other major communities of the district. The proportion of women having three or more children was highest among the Muslims. The desire to have more children was also highest among them in comparison to the Hindu and the tribal communities. Education and occupation of the mother were found to be associated with fertility. More than half of the study subjects did not have any sex preference. As educational level of the mothers had an inverse relationship with the number of children it is recommended that women be educated more and more so that the family size could be controlled. In areas where there is taboo against the use of conventional contraceptives, this can be an effective measure. Further studies which are larger in magnitude covering wider area are also recommended so that the scenario for the whole state can be ascertained.

\section{ACKNOWLEDGEMENT}

The authors acknowledge the valuable inputs of other researchers from which references were quoted. The authors also thank the various study participants of the study. 


\section{REFERENCES}

1. Meenakshi K, Sristhi S, Jai P, et al. Gender preference and fertility intensions amongst reproductive age female in an urban area of district Rohtak, Haryana. IJRD in Pharmacy and Life Sciences 2015;4(6):1846-51.

2. Mohammad A, Benrithung $M$, Kallur NS. Fertility behaviour and effect of son preference among the Muslims of Manipur, India. Journal of Anthropology Article ID 108236, 2014;2014:p. 5.

3. Puja D, Amarjeet S, Ashok J, et al. Preference for male child in two semi-urban communities of Pune. Journal of Postgraduate Medicine Education and Research 2013;47(3):144-7.
4. Anikit K, Kshatriya GK. Sex preference and fertility: a study among the ansaris of Meerut district, Uttar Pradesh. Stud Home Com Sci 2013;7(2):109-17.

5. Dilip CN, Brojeshwor HS. Impact of son preference on fertility indices in Manipur. International Journal of Management, Economics, and Social Sciences 2012;1(2):26-32.

6. Sharat NS, Manglem TS. Indicators of differential tribal fertility in Manipur. ISOR Journal of Humanities And Social Sciences 2012;5(6):22-7.

7. Govt of India. National Family Health Survey-4, Report 2015-16. Ministry of Health and Family Welfare. New Delhi. 